\title{
Cotyledonoid Leiomyoma of Uterus: A Case Report
}

\section{Uterusun Kotiledonoid Leiomyomu: Olgu Sunumu}

\author{
Şafak ERSÖZ'1, Havvanur TURGUTALP'1, Sevdegül MUNGAN', Gülname GÜVENDí', Süleyman GÜVEN²
}

Departments of ${ }^{1}$ Pathology and ${ }^{2}$ Obstetrics and Gynaecology, Karadeniz Technical University, Faculty of Medicine, TRABZON, TURKEY

\begin{abstract}
The diagnosis of uterine smooth muscle tumors is usually not difficult. Occasionally, benign tumors with an unusual growth pattern may cause some diagnostic confusion for pathologists who had not experienced such a tumor before. A fifty-one year old female patient had admitted to our gynecology outpatient clinics with abnormal uterine bleeding (menorrhagia) and undergone a surgery with a diagnosis of pelvic mass. A neoplasm consisting of spindle cell nodules with prominent hydropic degeneration was observed at pathological examination. Tumor cells were positive for vimentin, desmin and smooth muscle actin at immunohistochemical evaluation. Cotyledonoid leiomyomas are rare benign smooth muscle tumors of uterus which are recently defined in the literature. In this article we report a case of cotyledonoid leiomyoma of uterus with an exophytic growth pattern in the serosa and did not contain an intramural dissecting component.
\end{abstract}

Key Words: Leiomyoma, Uterine, Immunohistochemistry

\section{ÖZ}

Uterus düz kas tümörlerinin tanısı genellikle zor değildir. Bazen, nadir büyüme paternine sahip benign tümörler, bu konuda daha önce deneyimi olmayan patologlar için tanısal zorluğa neden olabilirler. Elli bir yaşında kadın hasta anormal uterin kanama (menoraji) nedeniyle Kadın Hastalıkları ve Doğum polikliniğine başvurdu. Hasta pelvik kitle tanısı ile opere edildi. Neoplazm, belirgin hidropik dejenerasyon gösteren iğsi hücreli nodüllerden oluşmaktaydı. İmmünhistokimyasal çalışmada tümör hücreleri vimentin, desmin ve düz kas aktini ile pozitif boyanma göstermiştir. Literatürde son zamanlarda tanımlanan kotiledonoid leiomyoma uterusun nadir benign düz kas tümörlerindendir. Bu makalede serozada ekzofitik büyüme paterni ile karakterli, intramural diseksiyon göstermeyen kotiledonoid leiomyoma vakasını sunduk.

Anahtar Sözcükler: Leiomyom, Uterus, İmmünohistokimya

\section{INTRODUCTION}

Leiomyoma is the most common tumor of the genital tract in women. The diagnosis of conventional leiomyomas is usually not difficult. Benign smooth muscle tumors with an unusual growth pattern may lead both gynecologists and pathologists to false diagnosis and overtreatment of the patients. For this purpose this variants of the tumor must be well known and kept in mind $(1,2)$. Hendrickson and Kempson had classified primary benign smooth muscle tumors in 3 categories as follows: 1- Leiomyomas with usual differentiation, 2- variants defined on the basis of cytological features or cellularity, and 3- with unusual patterns of growth (3).

Leiomyomas with unusual patterns of growth may be multinodular, multilobulated, or multifocal. They might exhibit an infiltrative pattern resembling malignant tumors at histological and macroscopic evaluation. Moreover multinodularity accompanied by perinodular hydropic

Received : 01.03.2010

Accepted : 23.07.2010 degeneration might be also present. Dissecting leiomyoma is an unusual variant of uterine leiomyoma. This term defines the leiomyomas which causes myometrium dissection. If this tumor exceeds to extrauterine adnexial area with an exophytic pattern, then this lesion is defined as cotyledonoid dissecting leiomyoma because of its macroscopic appearance resembling placental cotyledons (4). However, recently Roth et al had defined cotyledonoid leiomyoma as a new diagnostic term for benign smooth muscle tumors with an exophytic growth pattern which did not demonstrate myometrium dissection (5).

Here we report an unusual leiomyoma variant with hydropic degeneration and extra uterine exophytic growth pattern without myometrium dissection.

\section{CASE REPORT}

A 51-year-old woman had admitted to our gynecology outpatient clinics. She had an obstetric history of 4

Correspondence: Şafak ERSÖZ

Department of Pathology, Karadeniz Technical University, Faculty of Medicine, TRABZON, TURKEY

E-mail: ersozs@yahoo.com Phone: +90 4623775606 
gestations, 2 resulted with birth and 2 with spontaneous abortion. She had complaints of abnormal uterine bleeding (menorrhagia). Pelvic examination revealed a palpable mass and surgery was planned. Pelvic ultrasonographic examination demonstrated an exophytic mass of $85 \times 77$ $\mathrm{mm}$ dimensions in the fundus of uteri, with irregular and multinodular outline. Tumor markers were within normal range. The patient had undergone total abdominal hysterectomy and bilateral salpingo-oophorectomy operation.

At macroscopic examination uterus was 140x90x80 mm in dimensions and 200 grams in weight. In fundus of the uterus a serosal fleshy polypoid tumor mass was observed with soft consistency, irregular borders and $8 \times 7 \mathrm{~cm}$ dimensions which was attached to the fundus of the uterus with a tiny stalk. Cut surface demonstrated cystic degeneration and partly multinodularity (Figure 1). Adnexes were found to be grossly normal. Histological examination revealed a neoplasm consisting of disorganized tumoreous nodules with prominent hydropic degeneration areas (Figures 2,3). Cellularity was variable through the tumor areas and nuclear atypia or mitotic activity was absent. Stroma contained vessel structures of different size but vascular invasion was not observed. Coagulation necrosis was absent either. Congested vascular structures which caused the purplish macroscopic appearance of the tumor were observed at peripheral areas (Figure 4A, B). Perinodular hydropic degeneration was prominent (Figure 4C). The exophytic bulbous processes apparently resulted from prominent hydropic degeneration between smooth muscle

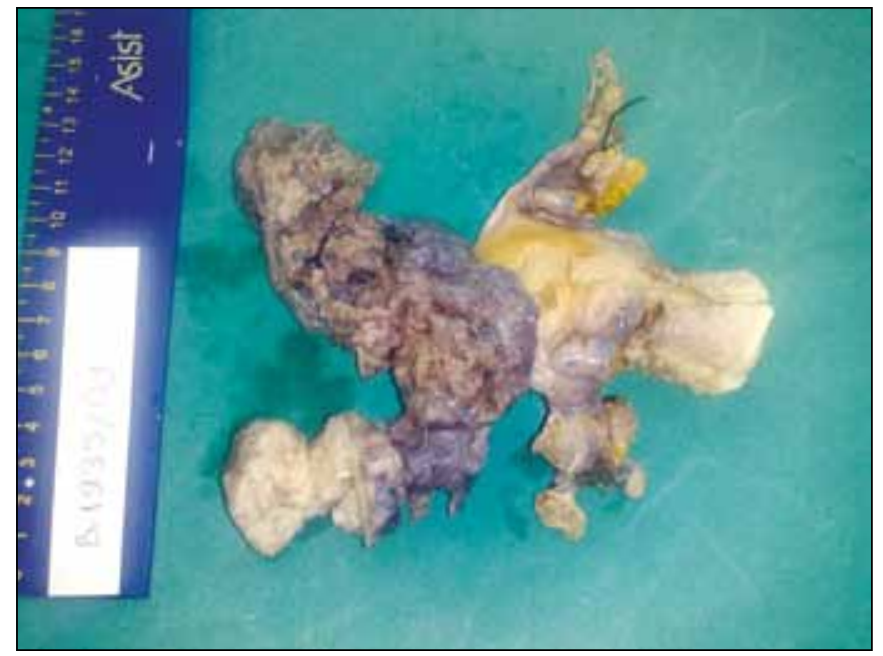

Figure 1: In fundus of the uterus a serosal, purple colored, fleshy polypoid tumor mass was observed with multinodularity and cystic degeneration. nodules. Immunohistochemical staining was performed in formaline-fixed and paraffin-embedded tissue sections. Avidin-biotin immunohistochemical technique was used for this purpose. Neoplastic cells were strongly positive for $\alpha$-smooth muscle actin (1A4,Neomarkers) (Figure 4D), Desmin (D33, Neomarkers), and Vimentin (SP20, Neomarkers), but negative for CD10 (56C6, Novacastra) and S-100 protein (4C4.9, Neomarkers). CD34 (QBEnd/10, Neomarkers) was only positive in vessel endothelial cells. Ki-67 (MB67, Neomarkers) index was 1\%. According to aforementioned pathological features a diagnosis of cotyledonoid leiomyoma was decided. Currently the

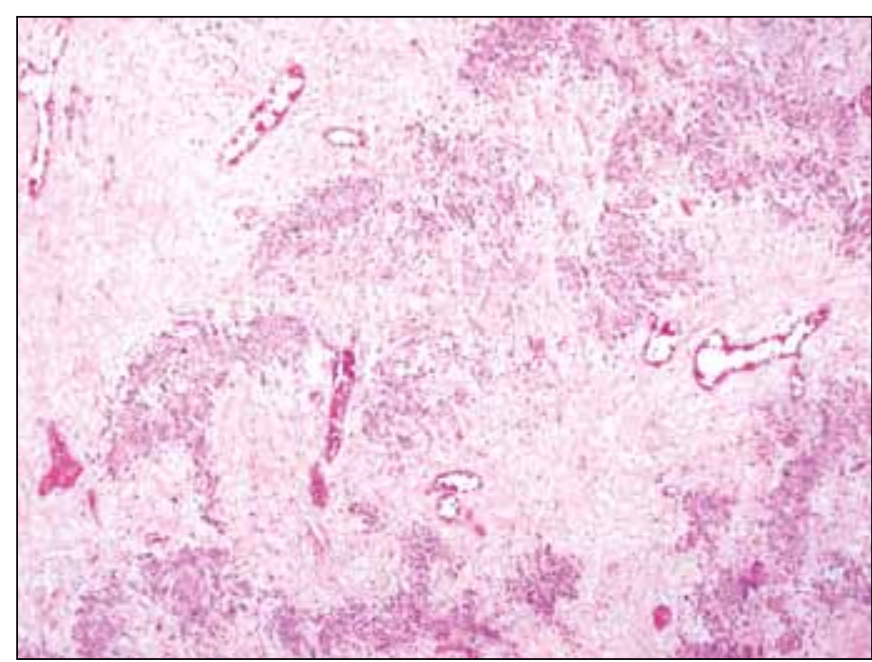

Figure 2: The slide obtained from the periphery of the tumor demonstrating congested and dilated vessels, smooth muscle nodules with irregular borders, and perinodular hydropic degeneration (H\&E; $\mathrm{x} 40)$.

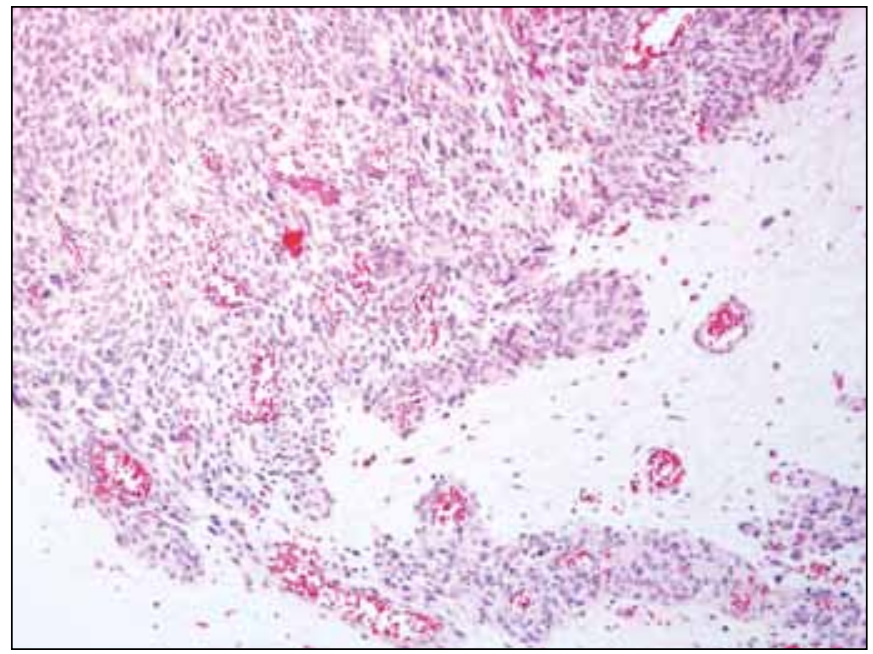

Figure 3: The slide demonstrating perinodular hydropic degeneration around the irregular bordered smooth muscle nodules at high power field (H\&E; x100). 

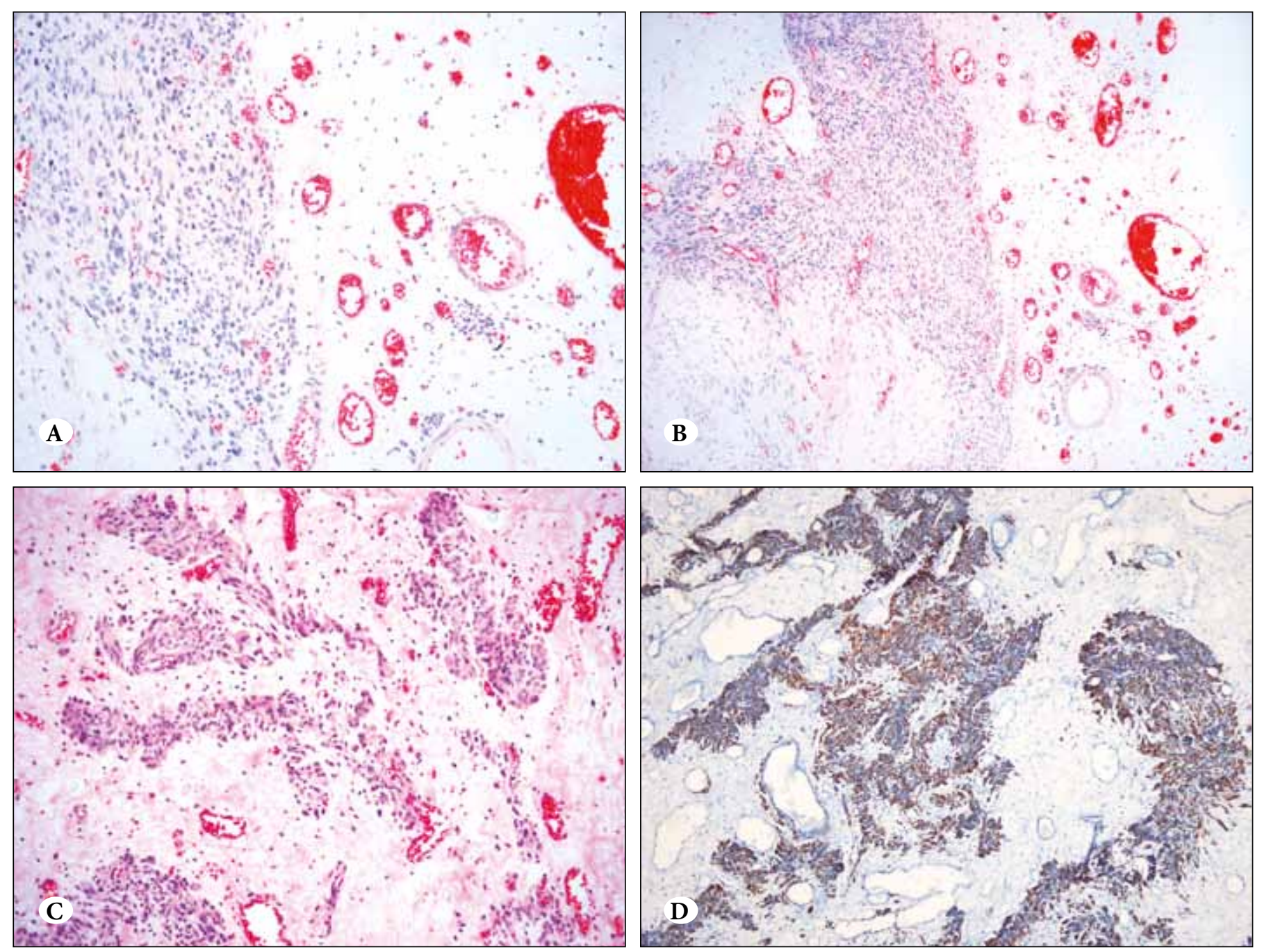

Figure 4: A,B: Congested vascular structures apparent at the peripheral areas of tumor (H\&E; x200-x40). C: Hydropic degeneration surrounding tumoreous nodules (H\&E; x200). D: Immunohistochemically, tumoreous nodules stained positive with smooth muscle $\operatorname{actin}(\mathrm{x} 100)$.

patient is well and healthy following the sixth month of the operation.

\section{DISCUSSION}

Uterine smooth muscle tumors demonstrate a wide variety of growth patterns. One unusual variant is the cotyledonoid dissecting leiomyoma of the uterus or "Sternberg tumor" which was first described in 1996 by Roth et al (6). Approximately 20 cases were reported in the literature. Cotyledonoid dissecting leiomyomas can be presented in a wide age range of patients between 23-65 years of age (mean 40.3). The most common clinical presentations are pelvic mass and abnormal uterine bleeding just as our current case. This type of tumor is usually large with an average dimension of $17.7 \mathrm{~cm}$ (7). In most of the reported cases, the gross appearance of the tumor had misled both clinicians and pathologists to malignity (8-10). Most of those cases had arisen from the fundus or the posterior aspect of the cornu of the uterus. Probably there is relatively more potential space for serosal tumor growth in these localizations. These cases demonstrated an exophytic component of bulbous (cotyledonoid) smooth muscle, grossly resembling placental tissue protruding from the uterine surface. This exophytic mass is usually in continuity with an intramural component dissecting the surrounding myometrium (4). Another variant called cotyledonoid leiomyoma was also described by Roth and Reed in 2000 (5). The tumor was located at the interface between the myometrium and the serosa producing exclusively exophytic growth pattern. In the previous reports of Roth et al, intramural dissection was accepted as an indicative pattern for both cotyledonoid and intramural dissecting leiomyomas. 
However, this new case which showed a great macroscopic resemblance to those types of dissecting leiomyomas did not demonstrate intramural dissection so it was accepted as a new intermediate tumor other than intramural and cotyledonoid dissecting leiomyoma (5). Both cotyledonoid dissecting and cotyledonoid leiomyomas demonstrate hydropic degeneration (4-6). As presented in our current case, hydropic degeneration may lead cystic degeneration.

According to our knowledge, our current cotyledonoid leiomyoma case which does not contain myometrium dissection is the third one following the original descriptive case of Roth et al and Gurbuz et al $(5,11)$.

The differential diagnosis of cotyledonoid leiomyomas includes intravenous leiomyomatosis and leiomyomas with perinodular hydropic changes. Intravenous leiomyomatosis grossly demonstrates multinodularity however exophytic component of the tumor does not show congestion. In the current case, the apparent purple color of the tumor was the result of congested vessels which were more prominent at the periphery of the mass. Leiomyomas with perinodular hydropic degeneration and cotyledonoid leiomyomas both demonstrate hydropic degeneration. Nevertheless the placenta like gross appearance of cotyledonoid leiomyomas can be discriminative which was also observed in our current case. Myxoid leiomyosarcoma should also be included in the differential diagnosis. Although myxoid leiomyosarcoma demonstrate malignant biological behavior, they do not have atypical cytology and mitotic activity is low as $0-2$ per ten high power fields. The main properties of the tumor which indicate the malignant potential are infiltrative growth pattern and high Ki-67 index $(>60 \%$ of tumor cells positive for $\mathrm{Ki}-67)$. In our current case Ki-67 index was quite low (1\%) and we could rule out myxoid leiomyosarcoma.
As a result, these types of exophytic smooth muscle tumors might demonstrate softer consistency and irregular borders in comparison with conventional leiomyomas. Grossly they might resemble malignant tumors and differential diagnosis might be problematic in microscopic evaluation. For this reason both gynecologic surgeons and pathologists should be well aware of these leiomyoma variants.

\section{REFERENCES}

1. Clement PB: Pure mesenchymal tumors. In Clement PB, Young RH. (Eds): Tumors and tumor like lesions of the uterine corpus and cervix. New York, Churchill Livingstone, 1993, 265-274

2. Kim MJ, Park YK, Cho JH: Cotyledonoid dissecting leiomyoma of the uterus: A case report and review of the literature. J Korean Med Sci 2002, 17: 840-844

3. Hendrickson MR, Kempson RL: Surgical pathology of the uterine corpus. Major Probl Pathol 1979, 12:1-580

4. Roth LM, Reed RJ: Dissecting leiomyomas of the uterus other than cotyledonoid dissecting leiomyomas. Am J Surg Pathol 1999, 23:1032-1039

5. Roth LM, Reed RJ: Cotyledonoid leiomyoma of the uterus: report of a case. Int J Gynecol Pathol 2000, 19:272-276

6. Roth LM, Reed RJ, Sternberg WH: Cotyledonoid dissecting leiomyoma of the uterus: the Sternberg tumour. Am J Surg Pathol 1996, 20:1455-1461

7. Saeed AS, Hanaa B, Faisal AS, Najla AM: Cotyledonoid dissecting leiomyoma of the uterus: a case report of a benign uterine tumor with sarcomalike gross appearance and review of literature. Int J Gynecol Pathol 2006, 25:262-267

8. David MP, Homonnai TZ, Deligdish L, Lowenthal M: Grapelike leiomyomas of the uterus. Int Surg 1975, 60:238-239

9. Payan H, Monges G, Jouve MP, Sudan N, Gamerre M: An unusual case of uterine leiomyoma: exophytic grape-like development in the pelvic peritoneum. Arch Anat Cytol Pathol 1980, 28:45-49

10. Cheuk W, Chan JK, Liu JY: Cotyledonoid leiomyoma: a benign uterine tumor with alarming gross appearance. Arch Pathol Lab Med 2002, 126: 210-213

11. Gurbuz A, Karateke A, Kabaca C, Arik H, Bilgic R: A case of cotyledonoid leiomyoma and review of the literature. Int J Gynecol Cancer 2005, 15:1218-1221 